\title{
In vitro and ex vivo anti-tumor effect and mechanism of Tucatinib in leukemia stem cells and ABCG2-overexpressing leukemia cells
}

\author{
WEN JING*, MAO ZHOU* , RUIXIA CHEN, XIJIU YE, WEIXING LI, \\ XIANGFEI SU, JIANWEI LUO, ZHI WANG and SHULING PENG
}

\begin{abstract}
Department of Anesthesiology, Sun Yat-Sen Memorial Hospital, Sun Yat-Sen University, Guangzhou, Guangdong 510289, P.R. China
\end{abstract}

Received June 13, 2020; Accepted November 20, 2020

DOI: $10.3892 /$ or.2020.7915

\begin{abstract}
Leukemia stem cells (LSCs), which evade standard chemotherapy, may lead to chemoresistance and disease relapse. The overexpression of ATP-binding cassette subfamily G member 2 (ABCG2) is an important determinant of drug resistance in LSCs and it can serve as a marker for LSCs. Targeting ABCG2 is a potential strategy to selectively treat and eradicate LSCs, and, hence, improve leukemia therapy. Tucatinib (Irbinitinib) is a novel tyrosine kinase inhibitor, targeting ErbB family member HER2, and was approved by the Food and Drug Administration in April 2020, and in Switzerland in May 2020 for the treatment of HER2-positive breast cancer. In the present study, the results demonstrated that tucatinib significantly improved the efficacy of conventional chemotherapeutic agents in ABCG2-overexpressing leukemia cells and primary leukemia blast cells, derived from patients with leukemia. In addition, tucatinib markedly decreased the proportion of leukemia stem cell-like side population (SP) cells. In SP cells, isolated from leukemia cells, the intracellular accumulation of Hoechst 33342 , which is an ABCG2 substrate, was significantly elevated by tucatinib. Furthermore, tucatinib notably inhibited the efflux of $\left[{ }^{3} \mathrm{H}\right]$-mitoxantrone and, hence, there was a higher level of $\left[{ }^{3} \mathrm{H}\right]-$ mitoxantrone in the HL60/ABCG2 cell line. The result from the ATPase assay revealed that tucatinib may interact with the drug substrate-binding site and stimulated ATPase activity of ABCG2. However, the protein expression level and cellular location of ABCG2 were not affected by tucatinib treatment. Taken together, these data suggested that tucatinib
\end{abstract}

Correspondence to: Dr Zhi Wang or Dr Shuling Peng, Department of Anesthesiology, Sun Yat-Sen Memorial Hospital, Sun Yat-Sen University, 33 Yingfeng Street, Dongxiao South Road, Guangzhou, Guangdong 510289, P.R. China

E-mail: wwzz1898@163.com

E-mail:pslmzk@aliyun.com

${ }^{*}$ Contributed equally

Key words: tucatinib, ABCG2, multidrug resistance, leukemia, leukemia stem cells could sensitize conventional chemotherapeutic agents, in ABCG2-overexpressing leukemia cells and LSCs, by blocking the pump function of the ABCG2 protein. The present study revealed that combined treatment with tucatinib and conventional cytotoxic agents could be a potential therapeutic strategy in ABCG2-positive leukemia.

\section{Introduction}

The unprecedented development of chemotherapeutics has been effective in the treatment of malignant leukemia; however, in 2013 the overall survival rate of patients with hematological malignancies was unsatisfactory, at only 40\% (1-3), as multidrug-resistance (MDR) disease eventually develops in the majority of patients. Intrinsic or treatment-induced acquired MDR, which is a phenomenon characterized by resistance to structurally and mechanistically unrelated drugs, is considered to be the primary reason for chemotherapeutic failure and leads to the death of patients with advanced leukemia (4). ATP-binding cassette (ABC) transporters have been widely considered to play pivotal roles in clinical drug resistance $(5,6)$. The overexpression of $\mathrm{ABC}$ transporter proteins, which function as active drug efflux pumps, can reduce the efficacy of anticancer drugs.

Among the ABC-protein family, the proteins encoded by the ABCB1 (P-gp), ABCC1 (MRP1) and ABCG2 (BCRP) genes have been associated with MDR. Previous studies have demonstrated that $\mathrm{ABCG} 2$ was associated with unsatisfactory chemotherapeutic effects, leading to a lower sensitivity to chemotherapy, an increased risk of relapse and a shorter disease-free survival rate in patients with acute lymphoblastic leukemia $(7,8)$. ABCG2 could be a promising therapeutic target for the eradication of leukemia stem cells (LSCs) (9), based on the evidence that ABCG2 was responsible for the identification and isolation of the 'side population' (SP) phenotype using flow cytometry, due to the efflux of Hoechst 33342 from tumor cells, with cancer stem cell characteristics (10). SP cells are highly rich in LSCs, which are responsible for asymmetric cell division, self-renewal capacity and the maintenance of leukemia $(11,12)$. Furthermore, ABCG2 facilitated the effusion of antineoplastic agents out of LSCs and plays a crucial role in the differentiation, proliferation and self-renewal of LSCs $(13,14)$. These results suggested that ABCG2 may be a promising therapeutic target for the eradication of LSCs. 
On account of their favorable therapeutic responses, tyrosine kinase inhibitors (TKIs) have been regarded as promising agents for the majority of patients with leukemia (15). TKIs have been found to not only directly inhibit the growth and metastasis of cancer cells (16), but also to enhance the anti-cancer effects of traditional chemotherapeutic agents by suppressing the drug transport activity of ABCG2, or by directly reducing the expression of ABCG2 (17). Therefore, combined treatment with TKIs and conventional cytotoxic agents may improve survival times.

Tucatinib (also known as ONT-380,ARRY380 or irbinitinib) is a small molecule taken orally $(480.532 \mathrm{~g} / \mathrm{mol})$, and a selective HER2 inhibitor for the treatment of HER2-positive solid tumors, including breast cancer (18) and colorectal cancer (19). Tucatinib was approved in the USA in April 2020 and in Switzerland in May 2020 for the treatment of HER2-positive breast cancer, which is the most aggressive type of breast cancer (20). Tucatinib has been proven to inhibit HER2 kinase activity, with nanomolar potency and to provide notable selectivity for HER2 compared with that for the related receptor tyrosine kinase, EGFR (19). Tucatinib is active as a single agent in multiple HER $2^{+}$tumor models and exhibits increased antitumor activity, when used in combination with conventional chemotherapeutic drugs, thereby increasing the rate of partial and complete tumor regression (21). Furthermore, tucatinib may provide an efficient therapeutic effect for patients with breast cancer and brain metastases, as it can penetrate the blood-brain barrier (22). Therefore, from these pre-clinical data, the present study aimed to determine whether tucatinib could also exert an inhibitory effect on hematological malignancies, with a high incidence of brain metastasis. The aim of current study was to investigate the effect of tucatinib on conventional chemotherapeutic agent retention in ABCG2-overexpressing leukemia cells and leukemia stem cells and characterize the interactions of tucatinib with ABCG2 transporters in primary leukemic blasts. The findings of the present study may provide new prospects for overcoming MDR of LSCs.

\section{Materials and methods}

Chemicals and reagents. Tucatinib (purity 99.38\%) was purchased from Selleck Chemicals. Topotecan, Hoechst 33342 , mitoxantrone, cisplatin and fumitremorgin C (FTC) were purchased from Sigma-Aldrich (Merck KGaA). RPMI-1640, DMEM, BSA, FBS, penicillin/streptomycin and $0.25 \%$ trypsin were purchased from Hyclone (GE Healthcare Life Sciences). $\left[{ }^{3} \mathrm{H}\right]$-mitoxantrone $(4 \mathrm{Ci} / \mathrm{mmol}$ ) was purchased from Moravek Biochemicals, Inc. The monoclonal antibody against ABCG2 was purchased from Santa Cruz Biotechnology, Inc., while the AlexaFluor488-conjugated goat anti-mouse IgG secondary antibody was purchased from Signet Laboratories Inc. HRP-conjugated rabbit anti-sheep IgG secondary antibody was purchased from Sigma-Aldrich (Merck KGaA), while the monoclonal antibody against GAPDH was purchased from Kangcheng BioTech Co., Ltd. Dimethylsulfoxide (DMSO), MTT and paraformaldehyde were purchased from Sigma-Aldrich (Merck KGaA). Mitoxantrone, topotecan and FTC were used as positive controls to confirm the mechanism of drug resistance in LSC models. Cisplatin (a non-substrate of ABCG2) was used as a negative control.
Cell lines and cell culture. The human HL60 and K562 leukemia cell lines were purchased from the Institute of Hematology and Blood Diseases Hospital, Chinese Academy of Medical Sciences and Peking Union Medical College (Tianjin, China). The HL60/ABCG2 and K562/ABCG2 cell lines (which overexpress ABCG2) were established, in the present study, by the transduction of the HL60 and K562 cell lines, respectively, with a HaMyBCRP retrovirus that contains Myc-tagged human BCRP (ABCG2) cDNA in Ha retrovirus vector (23-25). Subsequently, the transfected cells were selected using $4.0 \mu \mathrm{M}$ mitoxantrone for 7 days. The cell lines were cultured in RPMI-1640 containing 10\% FBS, $100 \mathrm{U} / \mathrm{ml}$ penicillin and $100 \mathrm{U} / \mathrm{ml}$ streptomycin, at $37^{\circ} \mathrm{C}$ in a humidified atmosphere with $5 \% \mathrm{CO}_{2}$, as previously described (23).

Cytotoxicity evaluation using a MTT assay. MTT (purity $99.59 \%$ ) reagent was used to determine the cell sensitivity to different chemotherapeutic agents (mitoxantrone, topotecan, cisplatin and tucatinib) with minor modifications (26). The $\mathrm{IC}_{50}$, which is defined as the drug concentration resulting in $50 \%$ cell death, was calculated from the cell survival curves using the Bliss method (27-29). The cells were collected and seeded in 96-well plates at $5 \times 10^{3}$ cells/well in $160 \mu \mathrm{l}$ medium. After culturing for $24 \mathrm{~h}$, the cells were pre-incubated with $0.1,0.2$ and $0.4 \mu \mathrm{M}$ tucatinib for a further $72 \mathrm{~h}$ at $37^{\circ} \mathrm{C}$. The cells were then treated with various concentrations of the chemotherapeutic agents by 2-fold dilution (mitoxantrone, 0.5-50 $\mu \mathrm{M}$; topotecan, 0.5-50 $\mu \mathrm{M}$; and cisplatin, 0.5-50 $\mu \mathrm{M}$ ) for a further $68 \mathrm{~h}$. Subsequently, $20 \mu \mathrm{l}$ MTT solution $(5 \mathrm{mg} / \mathrm{ml})$ was added to the cells, followed by further incubation for $4 \mathrm{~h}$ at $37^{\circ} \mathrm{C}$ then, the medium was discarded, and $200 \mu \mathrm{l}$ DMSO was added to dissolve the formazan product formed from the metabolism of MTT. The absorbance was determined at $540 \mathrm{~nm}$, with a background subtraction at $670 \mathrm{~nm}$, using a Model550 microplate reader (Bio-Rad Laboratories, Inc.) (30). The resistance fold change was calculated by dividing the $\mathrm{IC}_{50}$ values of the substrates, in the presence or absence of tucatinib, by the $\mathrm{IC}_{50}$ of the parental cells without the inhibitor treatment (23).

Patient samples. The present study was approved by the Ethics Review Committee at Sun Yat-Sen University. A total of 15 patients with leukemia were recruited into the study between June 2017 and April 2018; however, the bone marrow samples were obtained from 6 patients, at diagnosis, and randomly selected from a study pool of blast samples and examined. The patient population consisted of 2 males and 4 females, with a median age of 27 years. According to the French-American-British classification (31), three of the patients were diagnosed with acute lymphocytic leukemia, two of the patients were diagnosed with acute myeloid leukemia, and one patient was diagnosed with $\mathrm{T}$ lymphoblastic lymphoma. After the patients provided written informed consent, leukemia blasts were isolated using Ficoll-Hypaque density gradient centrifugation (at $300 \mathrm{x}$ g for $25 \mathrm{~min}$ at room temperature) and cultured in RPMI-1640, containing $20 \%$ FBS, with penicillin $(100 \mathrm{U} / \mathrm{ml})$ and streptomycin $(100 \mathrm{U} / \mathrm{ml})$ at $37^{\circ} \mathrm{C}$. Western blot analysis was performed to detect the protein expression level of ABCG2 in the patient samples. The patient characteristics are summarized in Table S1. 
SP analysis and sorting. The sorting and analysis of the SP cells was performed according to the methods described by Vieyra et al (32). In brief, the cells $\left(1 \times 10^{6}\right.$ cells $\left./ \mathrm{ml}\right)$ were cultured in prepared DMEM, containing $2 \%$ FBS and $10 \mathrm{mmol} / \mathrm{I}$ HEPES. Subsequently, $5 \mu \mathrm{g} / \mathrm{ml}$ Hoechst 33342 dye was added to the cells in the presence or absence of $10 \mu \mathrm{mol} / 1$ FTC. Following incubation for $90 \mathrm{~min}$, with intermittent shaking at $37^{\circ} \mathrm{C}$, the cells were washed twice with ice-cold PBS. The Hoechst dye was excited at $355 \mathrm{~nm}$, and the fluorescence profile was measured during the analysis (blue, 402-446 nm; red, 650-670 nm; MoFlo ${ }^{\mathrm{TM}}$ XDP; Beckman Coulter). The Summit v5.2 Software (Beckman Coulter) was used for the analysis.

Intracellular Hoechst 33342 accumulation assay. The HL60/ABCG2 cell lines $\left(1 \times 10^{5}\right)$ were cultured in 6 -well plates, containing various concentrations of tucatinib $(0.1,0.2$ and $0.4 \mu \mathrm{M}$ ) for $24 \mathrm{~h}$. Subsequently, $0.5 \mu \mathrm{g} / \mathrm{ml}$ Hoechst 33342 dye was added, followed by a further incubation for $30 \mathrm{~min}$ at $37^{\circ} \mathrm{C}$. Finally, the cells were washed with ice-cold PBS, three times and re-suspended in PBS for flow cytometric analysis (MoFlo ${ }^{\mathrm{TM}}$ XDP; Beckman Coulter). The Summit v5.2 Software (Beckman Coulter) was used for the analysis.

$\left[{ }^{3} \mathrm{H}\right]$-mitoxantrone accumulationassay. The $\left[{ }^{3} \mathrm{H}\right]$-mitoxantrone intracellular accumulation assay was used for the assessment of the reversal effects of tucatinib. In brief, the HL60, K562, HL60/ABCG2 and K562/ABCG2 cells $\left(5 \times 10^{5}\right)$ were suspended in RPMI 1640 medium, then incubated with or without 0.1 and $0.4 \mu \mathrm{M}$ tucatinib or $2.5 \mu \mathrm{M}$ FTC for $1 \mathrm{~h}$ at $37^{\circ} \mathrm{C}$. Subsequently, the cells were cultured in medium containing $0.1 \mu \mathrm{M}\left[{ }^{3} \mathrm{H}\right]$-mitoxantrone for a further $2 \mathrm{~h}$ at $37^{\circ} \mathrm{C}$. After washing twice with $10 \mathrm{ml}$ ice-cold PBS and lysed with $1 \%$ SDS (Ph 7.4), the radioactivity of the cells was measured. Each sample was placed in scintillation fluid $(5 \mathrm{ml})$, then the radioactivity was analyzed using a Packard TRI-CARB 1900CA liquid scintillation analyzer (PerkinElmer, Inc.), as described previously (33).

$\left[{ }^{3} \mathrm{H}\right]$-mitoxantrone efflux assay. Following the accumulation assay, the HL60, K562, HL60/ABCG2 and K562/ABCG2 cells $\left(5 \times 10^{5}\right)$ were suspended in RPMI 1640 medium, pre-incubated with or without 0.1 and $0.4 \mu \mathrm{M}$ tucatinib or $2.5 \mu \mathrm{M} \mathrm{FTC} \mathrm{for} 2 \mathrm{~h}$ at $37^{\circ} \mathrm{C}$. Subsequently, $0.1 \mu \mathrm{M}\left[{ }^{3} \mathrm{H}\right]$-mitoxantrone was added to each sample for $2 \mathrm{~h}$ at $37^{\circ} \mathrm{C}$, and following washing with ice-cold PBS, the cells were lysed at various time points $(0$, 30, 60 and $120 \mathrm{~min}$ ). Each sample was placed in scintillation fluid and the radioactivity was analyzed (Packard TRI-CARB 1900CA liquid scintillation analyzer; PerkinElmer, Inc.), as previously described (33). The Spectra Works2 ${ }^{\text {TM }}$ v2.0 STD and Quanta-Smart v5.2 Software (PerkinElmer, Inc.) were used for the analysis.

ATPase assay. The ABCG2-associated ATPase activity assay was determined using a SB-BRCP-M-PREDEASY-ATPase kit (TEBU-BIO nv,), with modified protocols (34). Cell membranes that overexpressed ABCG2 were incubated with an assay buffer containing $5 \mathrm{mM}$ sodium azide, $1 \mathrm{mM}$ ouabain, $2 \mathrm{mM}$ dithiothreitol, $10 \mathrm{mM} \mathrm{MgCl}$, $50 \mathrm{mM}$ potassium chloride, $2 \mathrm{mM}$ ethylene glycol-bis ( $\beta$-aminoethyl ether)-N,N,N',N'-tetra acetic acid, $50 \mathrm{mM}$ pH 6.8 2-(N-morpholino) ethanesulfonic acid MES and $0.3 \mathrm{mM}$ sodium orthovanadate $\left(\mathrm{Na}_{3} \mathrm{VO}_{4}\right)$ at $37^{\circ} \mathrm{C}$ for 5 min. $\mathrm{Na}_{3} \mathrm{VO}_{4}$ was used as an ATPase inhibitor. Various concentrations of tucatinib $(0-40 \mu \mathrm{M})$ were incubated with the membranes for $5 \mathrm{~min}$ at $37^{\circ} \mathrm{C}$. The ATPase reaction was initiated by the addition of $5 \mathrm{mM} \mathrm{Mg}^{2+}$ ATP. Luminescent signals of free phosphate group (Pi) were initiated and measured at $880 \mathrm{~nm}$ using a spectrophotometer (Bio Rad Laboratories, Inc.) following incubation at $37^{\circ} \mathrm{C}$ for $40 \mathrm{~min}$ with brief mixing. The changes in relative light units were determined by comparing $\mathrm{Na}_{3} \mathrm{VO}_{4}$-treated samples with the tucatinib-treated groups, using the colorimetric method (35).

Western blot analysis. Western blot analysis was performed to determine the protein expression levels of $\mathrm{ABCG} 2$, following treatment with $0.1,0.2,0.4$ and $1 \mu \mathrm{M}$ tucatinib for $48 \mathrm{~h}$ or with $0.4 \mu \mathrm{M}$ tucatinib for $0,24,36,48$ and $72 \mathrm{~h}$. The HL60/ABCG2 cells were incubated with $0,0.1,0.2,0.4$ and $1 \mu \mathrm{M}$ tucatinib for $12 \mathrm{~h}$, then harvested and washed twice with ice-cold PBS. The cell extracts were collected using a cell lysis buffer and protein concentration was determined using a BCA Protein assay kit (both from Thermo Fisher Scientific, Inc.) (36). Equal amounts of total cell lysates (30 $\mu \mathrm{g}$ protein) were resolved using a $10 \%$ SDS-PAGE and electrophoretically transferred onto PVDF membranes (EMD Millipore). The membranes were blocked with 5\% skimmed milk dissolved in TBS-Tween-20 (TBST) buffer $(10 \mathrm{mmol} / \mathrm{l}$ Tris-HCl, $150 \mathrm{mmol} / \mathrm{l} \mathrm{NaCl}$ and $0.1 \%$ Tween-20, $\mathrm{pH} 8.0$ ) for $2 \mathrm{~h}$ at room temperature. The membranes were then incubated with the primary monoclonal antibodies against GAPDH (cat. no. KC-5G4; 1:1,000) or ABCG2 (cat. no. MAB4145; clone BXP-34; $1: 200$ ) at $4^{\circ} \mathrm{C}$ overnight, then with HRP-conjugated secondary antibody (cat. no. AP147P; 1:1,000) at room temperature for $2 \mathrm{~h}$. Subsequently, the protein-antibody complexes were washed three times with TBST and protein bands were visualized using an enhanced chemiluminescence detection system (Phototope TM-HRP Detection kit; Cell Signaling Technology, Inc.) and the protein bands were analyzed using Scion Image v4.0.3 software (Scion Corporation). GAPDH was used as a loading control.

Immunofluorescence staining. The HL60/ABCG2 cells were cultured overnight in 24-well plates, then $0.4 \mu \mathrm{M}$ tucatinib was added to each well for further incubation for $72 \mathrm{~h}$. After washing with PBS, the treated cells were fixed with 4\% paraformaldehyde for $15 \mathrm{~min}$ and permeabilized using $0.1 \%$ Triton X-100 for $10 \mathrm{~min}$, both at room temperature. Subsequently, the cells were incubated with a monoclonal antibody against ABCG2 (cat. no. MAB4145; clone BXP-34; (1:500), overnight at $4^{\circ} \mathrm{C}$. Following incubation, the cells were washed with ice-cold PBS and incubated with an Alexa Fluor 488-conjugated goat anti-mouse $\operatorname{IgG}$ secondary antibody (cat. no. A-10684; 1:1,000) for $1 \mathrm{~h}$, at $4^{\circ} \mathrm{C}$. Immunofluorescence images were obtained using an inverted confocal microscope, and 6-8 random microscopic fields (magnification, $x 400$; model IX70; Olympus Corporation) with IX-FLA fluorescence and a Charge Coupled Devices camera.

Statistical analysis. Statistical analysis was performed using SPSS v16.0 software (SPSS, Inc.) and data are presented as 
Table I. Effect of tucatinib on reversing ABCG2-mediated MDR in the HL60/ABCG2 cells lines.

\begin{tabular}{|c|c|c|c|c|}
\hline \multirow[b]{2}{*}{ Compound } & \multicolumn{2}{|c|}{$\mathrm{IC}_{50} \pm \mathrm{SD}^{\mathrm{a}}, \mu \mathrm{M}$} & \multicolumn{2}{|c|}{ Resistance fold } \\
\hline & HL60 & HL60/ABCG2 & HL60 & HL60/ABCG2 \\
\hline Mitoxantrone & $0.727 \pm 0.058$ & $32.612 \pm 1.020$ & $1.00^{\mathrm{b}}$ & $44.858^{\mathrm{b}}$ \\
\hline +Tucatinib $0.1 \mu \mathrm{M}$ & $0.793 \pm 0.081$ & $6.522 \pm 0.098$ & 1.091 & $8.971^{\mathrm{d}}$ \\
\hline +Tucatinib $0.2 \mu \mathrm{M}$ & $0.730 \pm 0.092$ & $1.855 \pm 0.064$ & 1.004 & $2.552^{\mathrm{d}}$ \\
\hline +Tucatinib $0.4 \mu \mathrm{M}$ & $0.677 \pm 0.089$ & $0.603 \pm 0.043$ & 0.931 & $0.829^{\mathrm{d}}$ \\
\hline$+\mathrm{FTC} 2.5 \mu \mathrm{M}$ & $0.433 \pm 0.035$ & $0.509 \pm 0.038$ & $0.596^{\mathrm{c}}$ & $0.700^{\mathrm{d}}$ \\
\hline Topotecan & $0.684 \pm 0.044$ & $28.960 \pm 1.004$ & $1.00^{\mathrm{b}}$ & $42.339^{b}$ \\
\hline +Tucatinib $0.1 \mu \mathrm{M}$ & $0.496 \pm 0.053$ & $7.283 \pm 0.083$ & 0.725 & $10.645^{\mathrm{d}}$ \\
\hline +Tucatinib $0.2 \mu \mathrm{M}$ & $0.533 \pm 0.045$ & $4.021 \pm 0.079$ & 0.779 & $5.877^{\mathrm{d}}$ \\
\hline +Tucatinib $0.4 \mu \mathrm{M}$ & $0.401 \pm 0.039$ & $1.829 \pm 0.063$ & $0.586^{\mathrm{c}}$ & $2.674^{\mathrm{d}}$ \\
\hline +FTC $2.5 \mu \mathrm{M}$ & $0.376 \pm 0.053$ & $0.915 \pm 0.051$ & $0.550^{\mathrm{c}}$ & $1.337^{\mathrm{d}}$ \\
\hline Cisplatin & $15.561 \pm 0.971$ & $18.611 \pm 0.899$ & $1.00^{\mathrm{b}}$ & $1.00^{\mathrm{b}}$ \\
\hline +Tucatinib $0.4 \mu \mathrm{M}$ & $14.873 \pm 0.915$ & $19.799 \pm 0.926$ & 0.956 & 0.94 \\
\hline
\end{tabular}

${ }^{\mathrm{a}} \mathrm{C}_{50}$ values were determined using a MTT assay and the data are presented as the mean \pm SD from at least three independent experiments. ${ }^{b}$ Resistance fold of MDR was calculated by dividing the $\mathrm{IC}_{50}$ values of the resistant cells (HL60/ABCG2) by the $\mathrm{IC}_{50}$ of the parental cells (HL60) in the presence or absence of tucatinib or the positive control inhibitor, FTC. ${ }^{c} \mathrm{P}<0.05,{ }^{\mathrm{d}} \mathrm{P}<0.01$ vs. group treated with mitoxantrone or topotecan only. MDR, multidrug-resistance; FTC, fumitremorgin C.

A

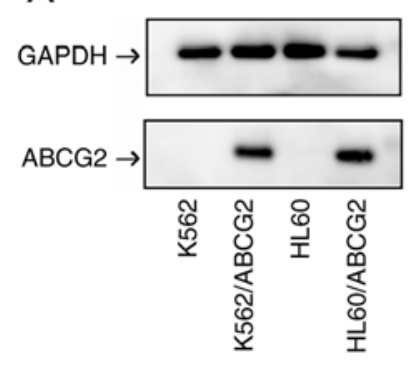

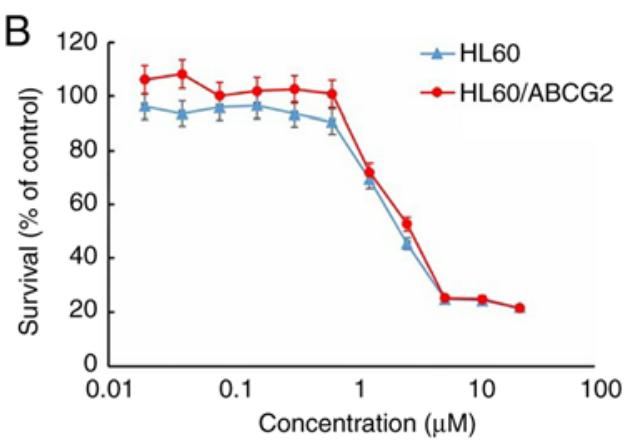

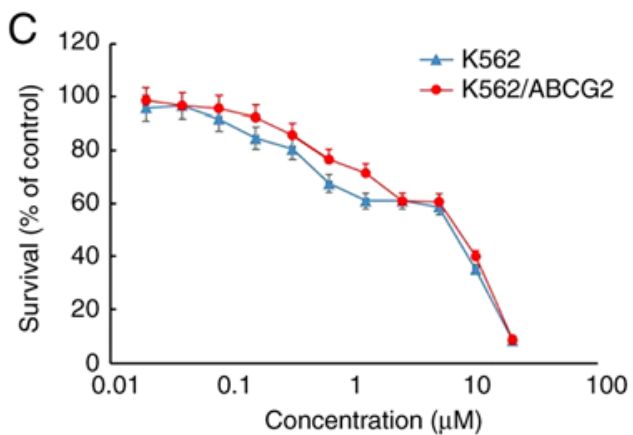

Figure 1. Cytotoxicity of tucatinib in the HL60, HL60/ABCG2, K562 and K562/ABCG2 cell lines. (A) Protein expression levels of ABCG2 in drug-resistant HL60/ABCG2, K562/ABCG2 cell lines and their parental, drug-sensitive HL60 and K562 cells lines. Cell viability of (B) HL60 and ABCG2-overexpressing HL60/ABCG2 and (C) K562 and ABCG2-overexpressing K562/ABCG2 cell lines. The data are presented as the mean \pm SD. Each experiment was performed three times, independently. ABCG2, ATP-binding cassette transporter ABCG2.

the mean $\pm \mathrm{SD}$, from 3-5 independent experiments. Statistical differences between 2 groups were determined using an unpaired Student's t-test. One-way ANOVA was used to determine differences between the means of multiple samples, with a Dunnett's post hoc test. $\mathrm{P}<0.05$ was considered to indicate a statistically significant difference.

\section{Results}

Tucatinib markedly potentiates the cytotoxicity of ABCG2 substrate anticancer drugs in leukemia cells. Prior to investigating the cytotoxicity of tucatinib, the protein expression levels of ABCG2 in the transfected cell lines were confirmed using western blot analysis. The protein expression levels of ABCG2 were overexpressed in the HL60/ABCG2 and K562/ABCG2 cell lines compared with that in the HL60 and K562 parental cell lines, respectively (Fig. 1A).
To investigate the effects of tucatinib on leukemia cells, MTT assays were subsequently performed to determine the cytotoxicity of tucatinib on 2 leukemia cell lines. As shown in Fig. $1 \mathrm{~B}$ and $\mathrm{C},>80 \%$ of the HL60/ABCG2 and K562/ABCG2 ABCG2-overexpressing cell lines, and their parental cell lines, HL60 and K562, survived $0.4 \mu \mathrm{M}$ tucatinib treatment. Therefore, $0.4 \mu \mathrm{M}$ tucatinib was selected as the maximum working concentration for further experiments. Subsequently, whether tucatinib, at various concentrations, could increase the sensitivity of ABCG2-overexpressing leukemia drug resistant cells to mitoxantrone and topotecan was investigated. As shown in Tables I and II, the ABCG2-overexpressing HL60/ABCG2 and $\mathrm{K} 562 / \mathrm{ABCG} 2$ cell lines showed higher $\mathrm{IC}_{50}$ values to the ABCG2 substrates, mitoxantrone and topotecan compared with that in their parental cell lines, respectively. In the presence of 0.1 and $0.2 \mu \mathrm{M}$ tucatinib, there was a significant increase in sensitivity of the cell lines to the two drugs. Tucatinib $(0.4 \mu \mathrm{M})$ 
Table II. Effect of tucatinib on reversing ABCG2-mediated multidrug resistance in K562/ABCG2 cells lines.

\begin{tabular}{|c|c|c|c|c|}
\hline \multirow[b]{2}{*}{ Compound } & \multicolumn{2}{|c|}{$\mathrm{IC}_{50} \pm \mathrm{SD}^{\mathrm{a}}, \mu \mathrm{M}$} & \multicolumn{2}{|c|}{ Resistance-fold ${ }^{b}$} \\
\hline & K562 & K562/ABCG2 & K562 & K562/ABCG2 \\
\hline Mitoxantrone & $1.003 \pm 0.013$ & $19.433 \pm 0.459$ & $1.00^{\mathrm{b}}$ & $19.375^{\mathrm{b}}$ \\
\hline +Tucatinib $0.1 \mu \mathrm{M}$ & $0.841 \pm 0.017$ & $5.608 \pm 0.087$ & 0.838 & $5.591^{\mathrm{d}}$ \\
\hline +Tucatinib $0.2 \mu \mathrm{M}$ & $0.649 \pm 0.018$ & $3.052 \pm 0.055$ & 0.647 & $3.043^{\mathrm{d}}$ \\
\hline +Tucatinib $0.4 \mu \mathrm{M}$ & $0.295 \pm 0.020$ & $0.979 \pm 0.075$ & $0.294^{\mathrm{c}}$ & $0.976^{\mathrm{d}}$ \\
\hline+ FTC $2.5 \mu \mathrm{M}$ & $0.219 \pm 0.004$ & $1.302 \pm 0.019$ & $0.218^{\mathrm{c}}$ & $1.298^{\mathrm{d}}$ \\
\hline Topotecan & $0.919 \pm 0.047$ & $18.772 \pm 0.761$ & $1.00^{\mathrm{b}}$ & $20.427^{b}$ \\
\hline +Tucatinib $0.1 \mu \mathrm{M}$ & $0.799 \pm 0.023$ & $4.771 \pm 0.079$ & 0.869 & $5.191^{\mathrm{d}}$ \\
\hline +Tucatinib $0.2 \mu \mathrm{M}$ & $0.589 \pm 0.022$ & $2.600 \pm 0.018$ & 0.641 & $2.829^{\mathrm{d}}$ \\
\hline +Tucatinib $0.4 \mu \mathrm{M}$ & $0.278 \pm 0.031$ & $0.898 \pm 0.054$ & $0.303^{\mathrm{c}}$ & $0.977^{\mathrm{d}}$ \\
\hline+ FTC $2.5 \mu \mathrm{M}$ & $0.317 \pm 0.027$ & $0.811 \pm 0.014$ & $0.345^{\mathrm{c}}$ & $0.882^{\mathrm{d}}$ \\
\hline Cisplatin & $15.810 \pm 1.733$ & $17.870 \pm 1.903$ & $1.00^{\mathrm{b}}$ & $1.00^{\mathrm{b}}$ \\
\hline +Tucatinib $0.4 \mu \mathrm{M}$ & $14.664 \pm 1.653$ & $15.829 \pm 1.833$ & 0.927 & 0.886 \\
\hline
\end{tabular}

${ }^{\mathrm{a}} \mathrm{IC}_{50}$ values were determined using a MTT assay. The data are presented as mean \pm SDs from at least three independent experiments. ${ }^{\mathrm{b}} \mathrm{Resis}-$ tance-fold of MDR was calculated by dividing the $\mathrm{IC}_{50}$ values of the resistant cells (K562/ABCG2) by the $\mathrm{IC}_{50}$ of parental cells (K562) in the presence or absence of tucatinib or positive control inhibitor, FTC. ${ }^{\mathrm{C}} \mathrm{P}<0.05,{ }^{\mathrm{d}} \mathrm{P}<0.01$ vs. group treated with mitoxantrone or topotecan only. MDR, multidrug-resistance; FTC, fumitremorgin C.

further increased the sensitivity of leukemia cells to the two drugs in both the ABCG2-overexpressing HL60/ABCG2 and K562/ABCG2 cell lines, and its efficacy was comparable to that of the known ABCG2 inhibitor, FTC $(2.5 \mu \mathrm{M})$. Conversely, tucatinib did not significantly alter the $\mathrm{IC}_{50}$ value of cisplatin in all the leukemia cell lines, which is a non-ABCG2 substrate. Taken together, these results suggested that tucatinib may significantly sensitize ABCG2-overexpressing leukemia cells to become anti-neoplastic.

Tucatinib significantly increases the cytotoxicity of conventional chemotherapeutic agents in leukemia blast cells, derived from patients with leukemia. ABCG2 is abundantly expressed in patients with acute leukemia and in LSCs (9). Thus, the present study examined the protein expression levels of ABCG2 and analyzed the cytotoxicity of mitoxantrone, with or without tucatinib treatment in leukemia blast cells derived from patients with leukemia (Fig. 2). The results demonstrated that 2/6 patient samples exhibited detectable expression levels of ABCG2 (Fig. 2A). Notably, treatment of the leukemia blast cells, with tucatinib, effectively increased their sensitivity to the cytotoxicity of mitoxantrone in two patient samples (Fig. 2B and $\mathrm{C}$ ). These results suggested that the combined use of tucatinib and mitoxantrone may achieve positive clinical effects.

Tucatinib significantly decreases the proportion of SP cells. In the present study, to investigate whether tucatinib has the potential to inhibit the proportion of SP cells, the population of SP cells in the HL60 cell line, treated with various concentrations of tucatinib were analyzed using flow cytometry. As shown in Fig. 3A and B, following treatment with $0.4 \mu \mathrm{M}$ tucatinib, the proportion of SP cells in the HL60 cell line was significantly decreased from 2.6 to $0.8 \%(\mathrm{P}=0.041)$ compared with that in the control cells, respectively. These results indicated that tucatinib significantly decreased the SP cell fraction in the HL60 cell line, in a dose-dependent manner.

Tucatinib significantly increases the intracellular levels of Hoechst 33342 in SP cells. The potentiation of antitumor activity by transporter inhibitor is typically mediated by inhibiting transporter-mediated drugs, resulting in increased intracellular drug accumulation (37). To determine whether tucatinib may potentiate the chemotherapeutic efficacy in SP cells, the intracellular accumulation levels of Hoechst 33342 were determined (known as fluorescent substrates of ABCG2) using flow cytometry. The results revealed that in the presence of $0.1,0.2$ and $0.4 \mu \mathrm{M}$ tucatinib, the relative values of Hoechst 33342 in SP cells were significantly increased by 0.85 $(\mathrm{P}=0.035)-, 0.92$ ( $\mathrm{P}=0.028)$ - and 1.195 ( $\mathrm{P}=0.024)$-fold, respectively (Fig. 4A and $\mathrm{C}$ ). These results indicated that tucatinib may significantly elevated the intracellular accumulation of Hoechst 33342 in a concentration-dependent manner in SP cells. Conversely, there was no significant difference in the intracellular levels of Hoechst 33342 in non-SP (NSP) cells treated with tucatinib and FTC.

Tucatinib effectively enhances the intracellular levels of anti-neoplastic drugs and antagonizes the drug efflux in ABCG2-overexpressing leukemia cell lines. To investigate the potential traverse mechanism by which tucatinib sensitized ABCG2-overexpressing leukemia cell lines, the intracellular levels of $\left[{ }^{3} \mathrm{H}\right]$-mitoxantrone were analyzed in the presence or absence of tucatinib. In the presence of 0.1 and $0.4 \mu \mathrm{M}$, tucatinib significantly increased the intracellular levels of $\left[{ }^{3} \mathrm{H}\right]$-mitoxantrone in the HL60/ABCG2 cell lines, but the accumulative effect of $\left[{ }^{3} \mathrm{H}\right]$-mitoxantrone following $0.4 \mu \mathrm{M}$ tucatinib was lower compared with that of FTC, at $2.5 \mu \mathrm{M}$, respectively (Fig. 5E). In addition, tucatinib, at $0.4 \mu \mathrm{M}$, 

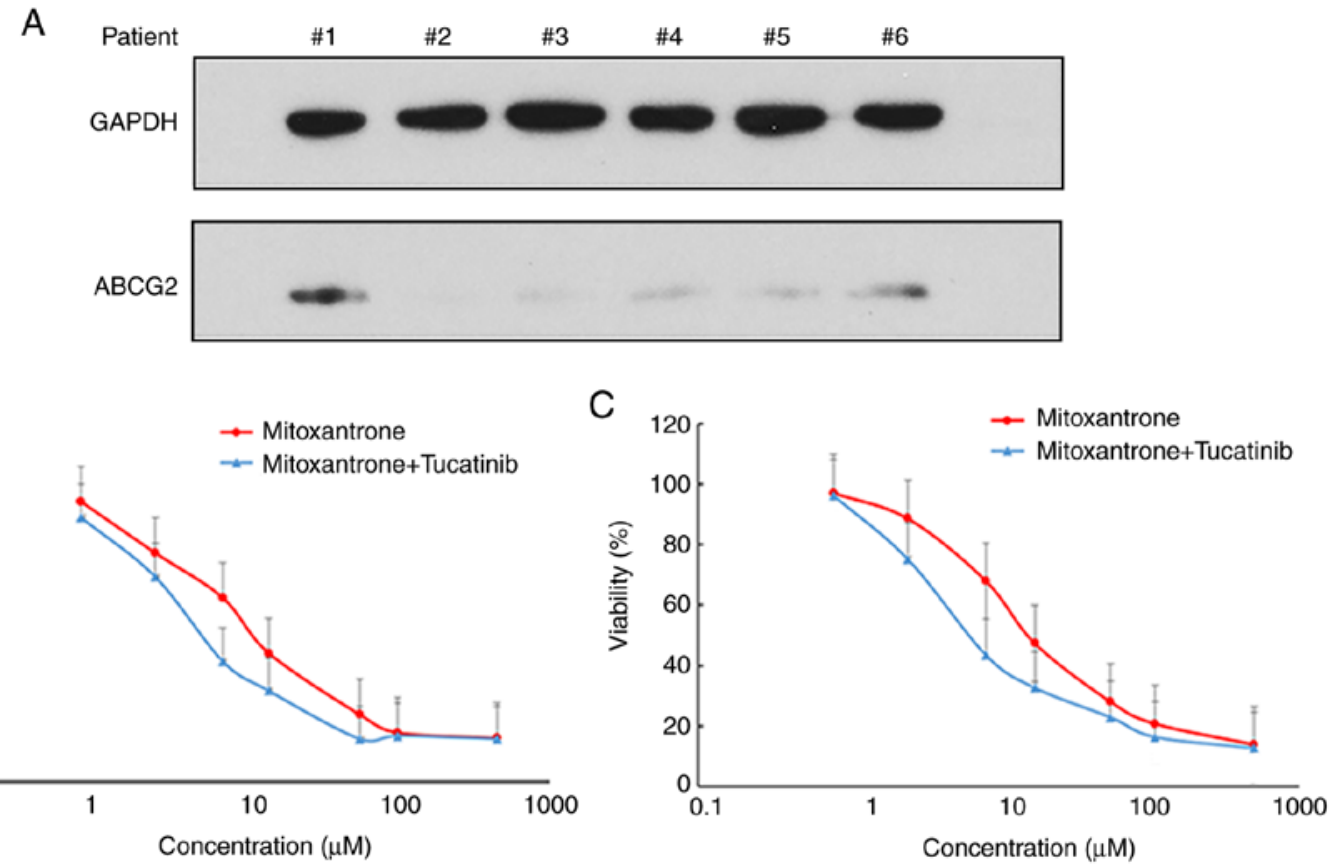

Figure 2. Tucatinib enhanced the cytotoxicity of mitoxentrane in primary leukemia blast cells derived from patients with leukemia. Bone narrow samples were collected from 6 patients with newly diagnosed leukemia. (A) The protein expression level of ABCG2 in leukemia blast cells derived from patients were detected using western blot analysis. GAPDH was used as the loading control. Samples from patient nos. 1 and 6 displayed detectable protein expression level of ABCG2. Enhancement of mitoxentrane cytotoxicity from tucatinib in primary cultures of leukemia blast cells from patient (B) no. 1 and (C) no. 6. The data are presented as the mean $\pm \mathrm{SD}$, from 3 independent experiments. ABCG2, ATP-binding cassette transporter ABCG2.
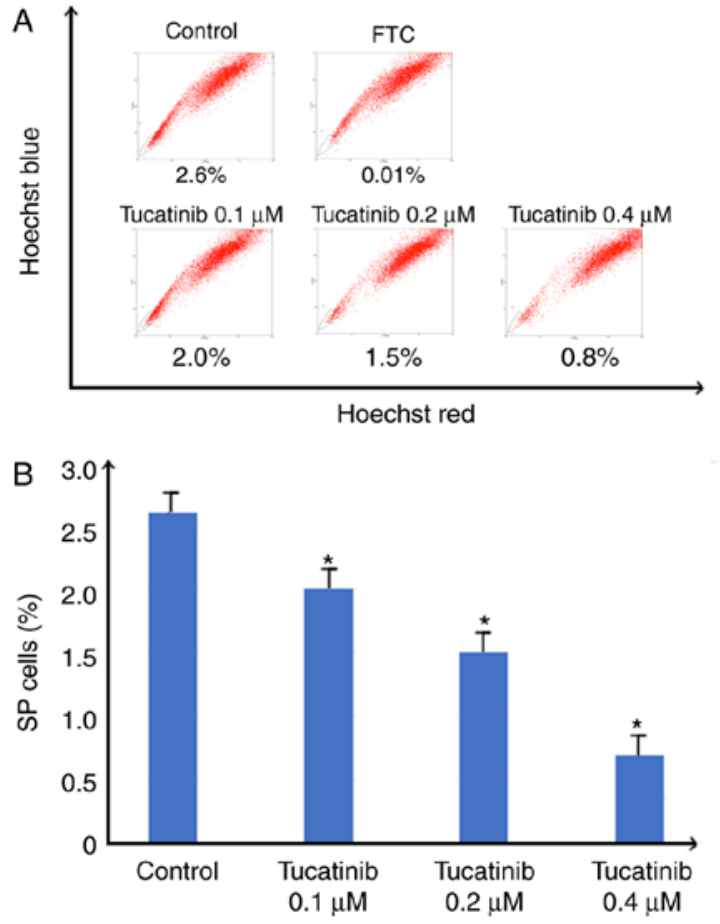

Figure 3. Efficiency of tucatinib on decreasing the proportion of SP cells. (A) HL60 was treated with $0.1,0.2$ and $0.4 \mu \mathrm{M}$ tucatinib for $48 \mathrm{~h}$, then stained with Hoechst 33342 followed by the SP analysis. Representative flow cytometry plots are shown. (B) The results were subsequently quantified. The data are presented as the mean \pm SD from 3 independent experiments. ${ }^{*} \mathrm{P}<0.05$ vs. control. SP, side population; FTC, fumitremorgin C.

significantly reduced the efflux of $\left[{ }^{3} \mathrm{H}\right]$-mitoxantronein close to the effect of FTC at $2.5 \mu \mathrm{M}$ in the HL60/ABCG2 cell lines
(Fig. 5B). Similarly, pretreatment of tucatinib also effectively improved the intracellular levels of $\left[{ }^{3} \mathrm{H}\right]$-mitoxantrone and decreased its efflux in K562/ABCG2 cells (Fig. 5D and F). Neither tucatinib nor FTC significantly affected the intracellular levels of $\left[{ }^{3} \mathrm{H}\right]$-mitoxantrone in the parental HL60 and K562 cells (Fig. 5A and C). These results indicated that tucatinib increased the intracellular levels of the antitumor drugs in a dose-dependent manner.

Tucatinib stimulates the ATPase activity of ABCG2. The drug efflux function of ABCG2 has been associated with ATP hydrolysis, which is mediated by the presence of its substrates or inhibitors (34). To further investigate the mechanisms involved for the potential of tucatinib to overcome MDR, the efficacy of tucatinib on the ATPase activity of ABCG2 transporters was determined, by measuring BCRP-mediated ATP hydrolysis in the presence or absence of $0-40 \mu \mathrm{M}$ tucatinib (Fig. 6A). As shown in Fig. 6B, using the colorimetric method, the maximum ATPase activities of ABCG2 increased to $114.28 \pm 8.91$ nmoles $\mathrm{P}_{\mathrm{i}} / \mathrm{mg}$ protein/min in the presence of tucatinib (from 0-10 $\mu \mathrm{M}$ ), the maximum stimulation was 4.28 -fold greater compared with that at the basal level. The concentration of tucatinib required to obtain $50 \%$ stimulation was $2.7 \mu \mathrm{M}$. These results suggested that tucatinib stimulated the ATPase activity of ABCG2 by interacting with the drug substrate-binding site, thereby restricting the efflux function of ABCG2.

Tucatinib does not alter the protein intracellular localization nor the expression levels of ABCG2 in the HL6O/ABCG2 cell line. To determine whether the antagonistic effects of tucatinib on MDR were achieved by altering $\mathrm{ABCG} 2$ protein expression levels or changing its subcellular localization, western blot and 
A

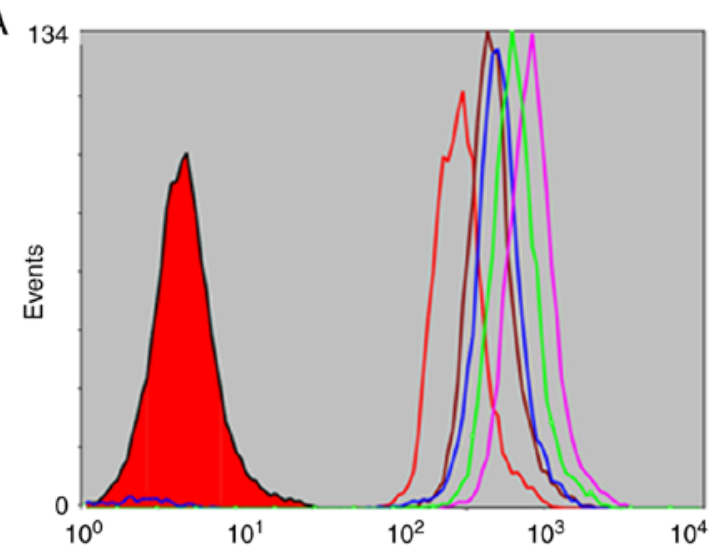

B

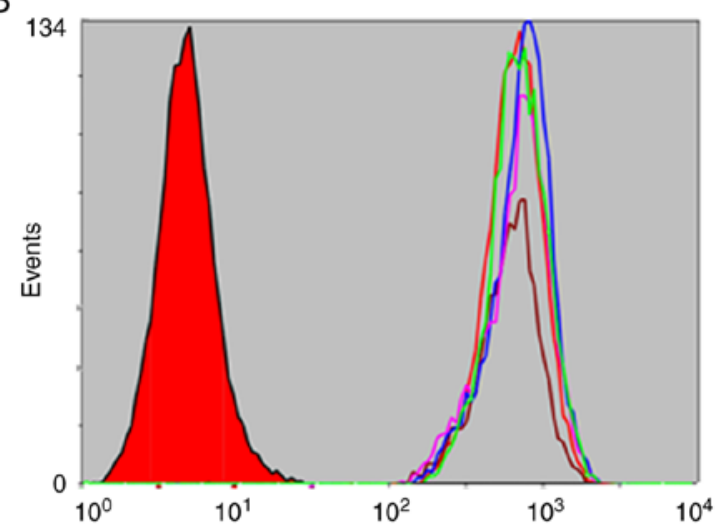

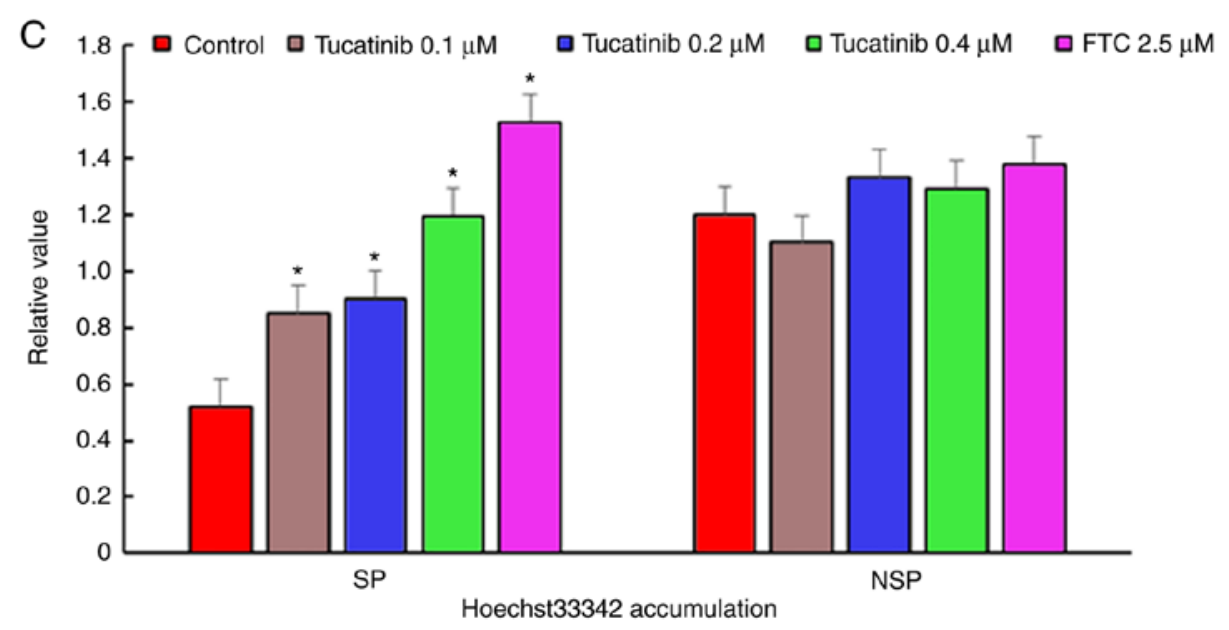

Figure 4. Efficiency of tucatinib on the accumulation of Hoechst 33342 in SP and NSP cells. The accumulation of Hoechst 33342 was measured using flow cytometry in (A) SP and (B) NSP cells, after the HL60 cell line was treated with different concentrations of tucatinib, then the results were subsequently (C) quantified. All experiments were repeated 3 times. The data are presented as the mean \pm SD. ${ }^{*} \mathrm{P}<0.05$ vs. control. SP cells, side population cells; NSP, non-side population cells; FTC, fumitremorgin C.

immunofluorescence analyses were performed. There were no notable changes in the cellular localization of ABCG2 transporters, following incubation with $0.4 \mu \mathrm{M}$ tucatinib for $72 \mathrm{~h}$ in the HL60/ABCG2 cell line (Fig. 7A). In addition, the ABCG2 protein expression level was not altered following $72 \mathrm{~h}$ of treatment with $0.4 \mu \mathrm{M}$ tucatinib or following treatment with $0.1,0.2,0.4$ or $1 \mu \mathrm{M}$ tucatinib for $48 \mathrm{~h}$ in the HL60/ABCG2 cell line. (Fig. 7B). These results indicated that the reversal effects of tucatinib were neither accomplished by altering the expression levels nor by affecting the intracellular localization of ABCG2 in the HL60/ABCG2 cell line.

\section{Discussion}

Over the past few decades, significant developments in chemotherapeutics have markedly improved clinical treatment efficacy for patients with acute leukemia (38). Standard induction therapy typically achieves short-term complete hematological remission; however, it has failed to improve overall survival times $(5,39)$. This may be due to the combined use of various chemotherapeutics, which leads to intrinsic or treatment-induced acquired MDR. MDR is a formidable impediment for achieving long-term remission in leukemia, and patients with MDR have to confront treatment failure, relapse and a poor prognosis (40). The main mechanism of
MDR is the aberrant activation of the agent efflux pumps of the ABC transporters, which leads to a decrease in the intracellular concentration of antineoplastic drugs and weakens the cytotoxicity of the drugs (41). In humans, two members of the $\mathrm{ABC}$ family of transporters, the breast cancer resistance protein (BCRP or ABCG2) and multidrug resistance protein (ABCB1) have been established to play pivotal roles in the anti-neoplastic resistance of malignant leukemia $(42,43)$. ABCG2 has attracted increasing attention due to its multiple pharmacological binding sites for nilotinib, imatinib and dasatinib. For example, a previous meta-analysis revealed that ABCG2 was a potential predictor of the efficacy of chemotherapy in chronic myeloid leukemia (CML), as overexpressed ABCG2 conferred poor effects to conventional anticancer drugs (44). In addition, accumulating data has suggested that ABCG2 was abundantly expressed in LSCs, and could be responsible for the proliferation and self-renewal ability of LSCs $(14,45)$. ABCG2 protects the LSCs from cytotoxicity by reducing the intracellular concentrations of antitumor drugs (42). Therefore, a subpopulation of LSCs may survive standard chemotherapy, maintaining malignant potential, leading to an eventual cancer recurrence. Furthermore, the fluorescent dye Hoechst 33342, as one of the ABCG2 substrates, has been widely used to identify and isolate the cancer stem cell population in pharmacological assays (46). 
A

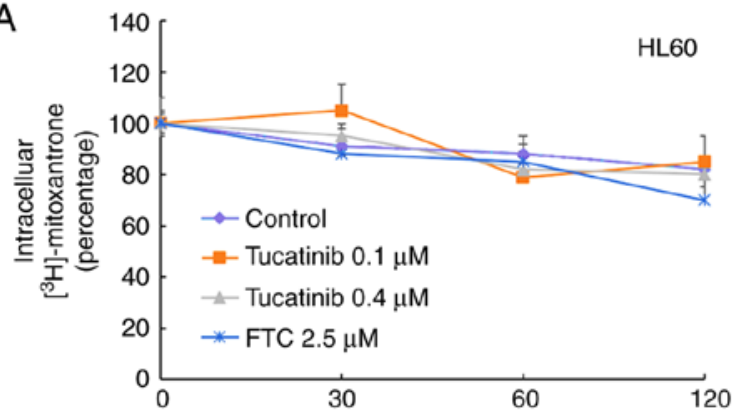

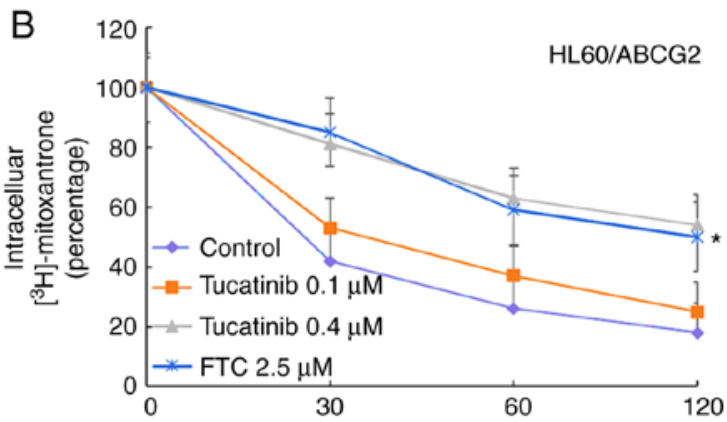

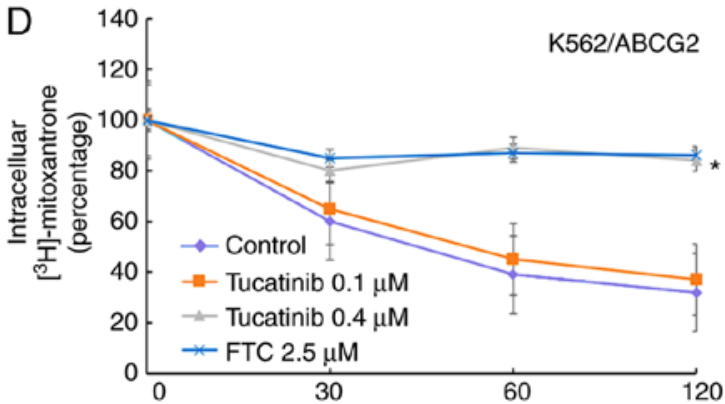

C

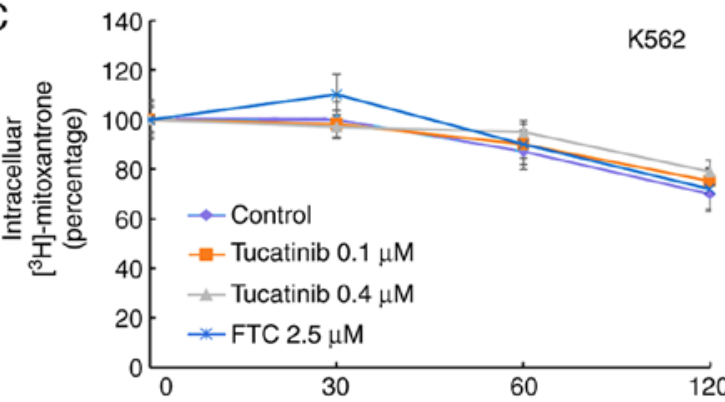

$\mathrm{E}$

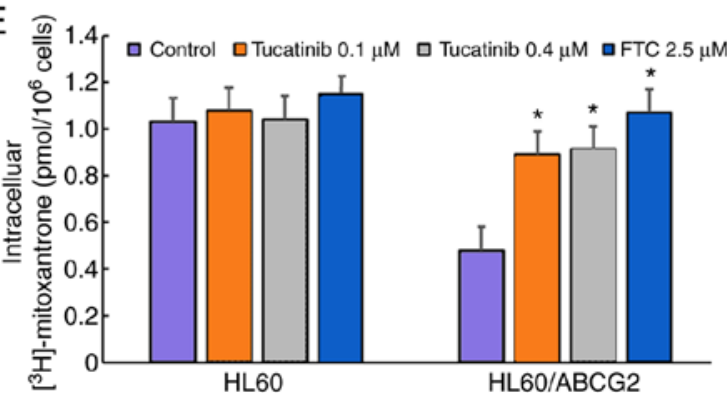

$\mathrm{F}$

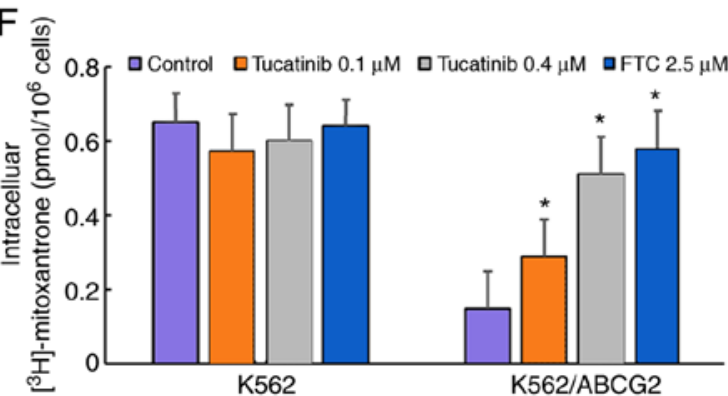

Figure 5. Efficiency of tucatinib on efflux and the intracellular levels of $\left[{ }^{3} \mathrm{H}\right]$-mitoxantrone. The effect of the [ $\left.{ }^{3} \mathrm{H}\right]-\mathrm{mitoxantrone}$ efflux in the (A) HL60, (B) ABCG2-overexpressing HL60/ABCG2, (C) K562 and (D) ABCG2-overexpressing K562/ABCG2 cell lines was determined following treatment with different concentrations of tucatinib $(0.1$ and $0.4 \mu \mathrm{M})$ and FTC $(2.5 \mu \mathrm{M})$, alone. The effect of tucatinib $(0.1$ and $0.4 \mu \mathrm{M})$ and $\mathrm{FTC}(2.5 \mu \mathrm{M})$ on the accumulation of $\left[{ }^{3} \mathrm{H}\right]$-mitoxantrone in (E) drug-resistant HL60/ABCG2 and its parental, drug-sensitive HL60 cell lines and (F) K562/ABCG2 and its parental, drug-sensitive K562 cells lines. The results are presented as the mean \pm SD from three independent experiments. * $<<0.05$ vs. control. ABCG2, ATP-binding cassette transporter ABCG2; FTC, fumitremorgin C.

Thus, ABCG2 may have potential for use in the development of novel chemical sensitizers targeting drug-resistant leukemia cells and for eradicating LSCs.

TKIs are a new type of highly specific and promising antitumor drugs, which have been demonstrated to be safe and effective agents for the treatment of various malignancies $(47,48)$. Furthermore, it has been demonstrated that dasatinib or nilotinib (second generation ABL-TKIs) may efficiently reduce the number of CML stem cells (49). Tucatinib is a new type of ATP-competitive and reversible HER2-targeted small-molecular TKI, which was approved in the USA in April 2020 and in Switzerland in May 2020 for the treatment of HER2-positive breast cancer, is pending regulatory review in the EU, Australia, Canada and Singapore, and approved in combination with other drugs, in patients with HER2-positive breast cancer and brain metastases (20). Tucatinib is active as a single agent in multiple HER $2^{+}$tumor models and it exhibits potent antitumor activity in combined treatment with conventional chemotherapeutic drugs, thereby increasing the rate of partial and complete tumor regression (18). Therefore, the aim of the present study was to investigate the interaction of tucatinib with the ABCG2 transporter and its ability to eradicate LSCs.

The results from the cytotoxicity assays demonstrated that tucatinib, at a non-toxic concentration, significantly potentiated the cytotoxicity of conventional chemotherapeutic agents in ABCG2-overexpressing leukemia cells in a dose-dependent manner. However, tucatinib treatment did not affect the cytotoxicity of cisplatin (a non-substrate of ABCG2). These results suggested that the preferable anti-neoplastic effects of tucatinib on leukemia cells may be attributed to its specific effect on ABCG2 transporters. The present study also revealed that tucatinib treatment significantly enhanced the cytotoxicity of mitoxantrone in ABCG2-overexpressing primary leukemia blast cells derived from patients with leukemia. In addition, flow cytometric assays revealed that tucatinib significantly decreased the proportion of LSCs-like SP cells in the HL60 cell line, which are typically used in the identification and isolation of cancer stem-like cells. In the SP cells, isolated from leukemia cells, the intracellular levels of Hoechst 33342, which is an ABCG2 substrate, were significantly elevated. 

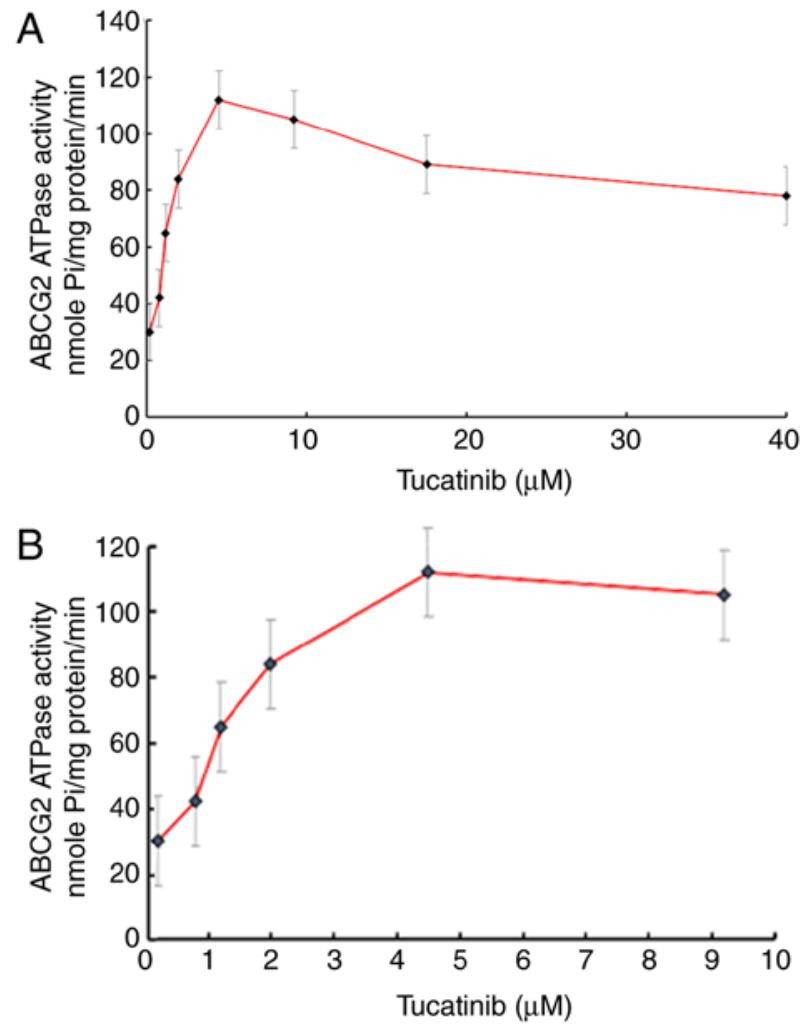

Figure 6. Tucatinib stimulated the ATPase activity of ABCG2 in the HL60/ABCG2 cell line. Effect of (A) 0-40 $\mu \mathrm{M}$ and (B) tucatinib on the ATPase activity of ABCG2. The data are presented as the mean $\pm \mathrm{SD}$, from 3 independent experiments.

The significant antitumor activity of transporter inhibitors is typically regulated by the inhibition of the transporter-mediated efflux, leading to an increase in the intracellular drug levels (28). Therefore, the intracellular levels and efflux of $\left[{ }^{3} \mathrm{H}\right]$-mitoxantrone were analyzed in leukemia cells in the presence or absence of tucatinib. The results demonstrated that tucatinib inhibited the efflux of $\left[{ }^{3} \mathrm{H}\right]$-mitoxantrone and, hence, there were higher levels of $\left[{ }^{3} \mathrm{H}\right]$-mitoxantrone in the HL60/ABCG2 and K562/ABCG2 cell lines.

It has been previously proposed that ABCG2 inhibitors can be divided into two subtypes: One that only inhibits ABCG2 activity and the other that suppresses ABCG2 activity in addition to reducing the expression levels of ABCG2 (17). Thus, the protein expression level and the intracellular location of ABCG2, at various concentrations of tucatinib was analyzed using western blot and immunofluorescence analyses. The results revealed that there was no notably decrease in the protein expression levels of ABCG2 following $72 \mathrm{~h}$ incubation with $0.4 \mu \mathrm{M}$ tucatinib or following tucatinib treatment at $0.1,0.2,0.4$ and $1 \mu \mathrm{M}$ for $48 \mathrm{~h}$ in the HL60/ABCG2 cell line. Furthermore, treatment with $0.4 \mu \mathrm{M}$ tucatinib did not affect the intracellular locations of the ABCG2 transporter.

Several studies have indicated that the HER2-specific TKIs, which bind to the extracellular domains of HER2, can compete with the ATP-TKIs domain, block tyrosine phosphorylation and signal events downstream of ligand binding (50). Tucatinib, which belongs to the ATP-competitive and highly selective small-molecule TKIs of anti-HER2 compounds,
A
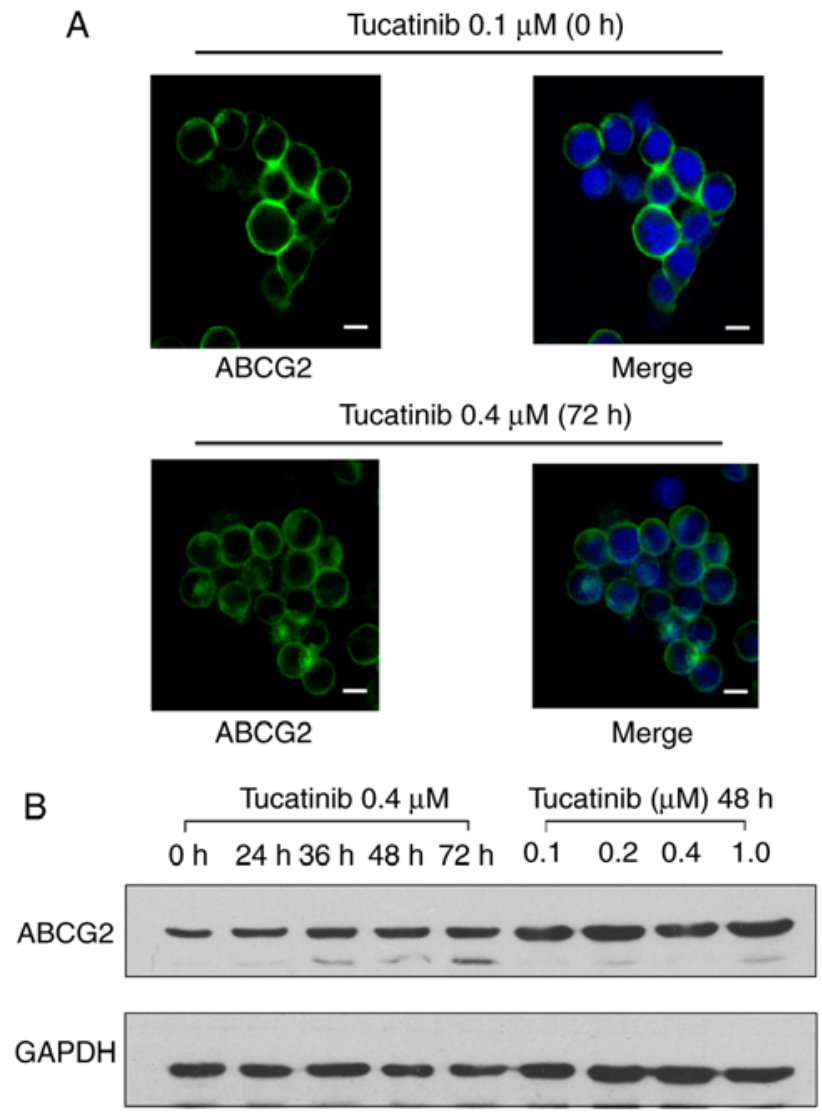

Figure 7. Efficiency of tucatinib on the subcellular location and protein expression levels of ABCG2 in the HL60/ABCG2 cell line. (A) Immunofluorescent staining was used to investigate the subcellular localization of ABCG2 in the HL60/ABCG2 cell line following treatment with tucatinib at $0.4 \mu \mathrm{M}$ for $72 \mathrm{~h}$. ABCG2 staining is showed in green and DAPI (blue) was used to counterstain the nuclei. Scale bar, $10 \mu \mathrm{m}$. (B) The HL60/ABCG2 cell line was treated with either tucatinib at $0.4 \mu \mathrm{M}$ for $72 \mathrm{~h}$ or treated with $0,0.1,0.2,0.4$ and $1 \mu \mathrm{M}$ for $48 \mathrm{~h}$. ABCG2, ATP-binding cassette subfamily $\mathrm{G}$ member 2 .

may exert similar effects. Thus, the present study investigated the effects of tucatinib on the ATPase activities of ABCG2 transporters in the HL60/ABCG2 cell line. The results demonstrated that tucatinib could stimulate the ATPase activity of ABCG2 transporters. These results were consistent with those of previous studies on the TKI pathway (51). Tucatinib may act as a substrate of ABCG2, which can compete with chemotherapeutic agents to occupy the binding site of ABCG2, increase ATPase activity and replace the antitumor drugs from the ABCG2 transporter. As a result, it suppresses the efflux function and increases the intracellular accumulation of substrate agents, leading to the reversal of MDR.

In recent years, a number of reversal reagents have been developed to suppress the $\mathrm{ABC}$ transporter-mediated MDR; however, due to the unpredictable results of their combined use with chemotherapeutic drugs, the majority of these reagents have failed in clinical practice $(37,40)$. Nevertheless, tucatinib, as an oral selective HER2 TKI, may have the ability to cure leukemia, when used in combination with other anti-tumor drugs, to reverse MDR induced by ABCG2 overexpression. Recent clinical trials indicated that tucatinib combined with trastuzumab and capecitabine, resulted in better progression-free survival and overall survival outcomes than without adding tucatinib in HER2-positive metastatic 
breast cancer (52), and with and without brain metastases (53). Thereby, the results from the present study suggests that the combined use of tucatinib with ABCG2 substrate-drugs may be a potential prospective treatment strategy to overcome resistance in patients with leukemia.

In conclusion, tucatinib may significantly enhance the chemosensitivity of ABCG2-overexpressing leukemia cells and LSCs to classic anti-tumor agents by inhibiting the drug efflux functions of ABCG2. Notably, the combined use of tucatinib with ABCG2 substrate anticancer drugs may be beneficial for patients with leukemia to elude the MDR of leukemia cells. In addition, the combined use of tucatinib with the ABCG2 substrate drugs may enhance the anti-tumor effects of anticancer drugs in vitro and in patient-derived leukemic blast cells. Thus, the results from the present study suggested that the use of tucatinib in combination with conventional chemotherapeutic drugs may prove to be a potential therapeutic strategy to improve the cytotoxicity of anti-tumor drugs and decrease the recurrence rate of ABCG2-overexpressing leukemia.

In summary, combination of tucatinib with the ABCG2 substrate drugs increased the antitumor effect of anticancer drugs in vitro and patient-derived leukemic blast cells. Therefore, this may be a potential therapeutic strategy to improve the cytotoxicity of antitumor drugs and decrease the recurrence rate in ABCG2 overexpressing leukemia cells.

\section{Acknowledgements}

Not applicable.

\section{Funding}

No funding was received.

\section{Availability of data and materials}

All data generated and/or analyzed during this study are included within the article.

\section{Authors' contributions}

$\mathrm{ZW}$ and SP designed the research and revised the manuscript. WJ, MZ and RC designed the methods and experiments, performed the laboratory experiments, analyzed the data, interpreted the results and wrote the paper. XY, XS, JL and WL co-designed the experiments and discussed the analyses, interpretation and presentation of the data. All authors approved the final version of the manuscript.

\section{Ethics approval and consent to participate}

The experimental protocol for the use of patient samples was reviewed and approved by the Ethics Review Committee at Sun Yat-Sen University. Informed consent was provided by each patient.

\section{Patient consent for publication}

Not applicable.

\section{Competing interests}

The authors declare that they have no competing interests.

\section{References}

1. Bouvy C, Wannez A, Laloy J, Chatelain C and Dogné JM: Transfer of multidrug resistance among acute myeloid leukemia cells via extracellular vesicles and their microRNA cargo. Leuk Res 62: 70-76, 2017.

2. Hochhaus A, Ernst T, Eigendorff E and La Rosée P: Causes of resistance and treatment choices of second- and third-line treatment in chronic myelogenous leukemia patients. Ann Hematol 94 (Suppl 2): S133-S140, 2015

3. Takeshita A: Efficacy and resistance of gemtuzumab ozogamicin for acute myeloid leukemia. Int J Hematol 97: 703-716, 2013.

4. Tesfatsion DA: Dendritic cell vaccine against leukemia: Advances and perspectives. Immunotherapy 6: 485-496, 2014.

5. Valera ET, Scrideli CA, de Paula Queiroz RG, Mori BM and Tone LG: Multiple drug resistance protein (MDR-1), multidrug resistance-related protein (MRP) and lung resistance protein (LRP) gene expression in childhood acute lymphoblastic leukemia. Sao Paulo Med J 122: 166-171, 2004.

6. Steinbach D and Legrand O: ABC transporters and drug resistance in leukemia: Was P-gp nothing but the first head of the hydra? Leukemia 21: 1172-1176, 2007.

7. Plasschaert SL, Van Der Kolk DM, De Bont ES, Vellenga E, Kamps WA and De Vries EG: Breast cancer resistance protein (BCRP) in acute leukemia. Leuk Lymphoma 45: 649-654, 2004.

8. Bram EE, Stark M, Raz S and Assaraf YG: Chemotherapeutic drug-induced $\mathrm{ABCG} 2$ promoter demethylation as a novel mechanism of acquired multidrug resistance. Neoplasia 11: 1359-1370, 2009.

9. Damiani D, Tiribelli M, Geromin A, Michelutti A, Cavallin M, Sperotto A and Fanin R: ABCG2 overexpression in patients with acute myeloid leukemia: Impact on stem cell transplantation outcome. Am J Hematol 90: 784-789, 2015.

10. Smith PJ, Furon E, Wiltshire M, Campbell L, Feeney GP, Snyder RD and Errington RJ: ABCG2-associated resistance to Hoechst 33342 and topotecan in a murine cell model with constitutive expression of side population characteristics. Cytometry A 75: 924-933, 2009.

11. Moshaver B, Wouters RF, Kelder A, Ossenkoppele GJ, Westra G, Kwidama Z, Rutten AR, Kaspers G, Zweegman S, Cloos J and Schuurhuis GJ: Relationship between CD34/CD38 and side population (SP) defined leukemia stem cell compartments in acute myeloid leukemia. Leuk Res 81: 27-34, 2019.

12. Hanekamp D, Cloos J and Schuurhuis GJ: Leukemic stem cells: Identification and clinical application. Int J Hematol 105: 549-557, 2017.

13. Abbott BL: ABCG2 (BCRP): A cytoprotectant in normal and malignant stem cells. Clin Adv Hematol Oncol 4: 63-72, 2006.

14. Patrawala L, Calhoun T, Schneider-Broussard R, Zhou J, Claypool K and Tang DG: Side population is enriched in tumorigenic, stem-like cancer cells, whereas $\mathrm{ABCG} 2^{+}$and $\mathrm{ABCG} 2$-cancer cells are similarly tumorigenic. Cancer Res 65: 6207-6219, 2005.

15. Yazdi MH,Faramarzi MA,Nikfar S and Abdollahi M: Comparative safety and efficacy of tyrosine kinase inhibitors (TKIs) in the treatment setting of different types of leukemia, and different types of adenocarcinoma. Biomed Pharmacother 95: 1556-1564, 2017.

16. Hegedus C, Ozvegy-Laczka C, Apáti A, Magócsi M, Német K, Orfi L, Kéri G, Katona M, Takáts Z, Váradi A, et al: Interaction of nilotinib, dasatinib and bosutinib with ABCB1 and ABCG2: Implications for altered anti-cancer effects and pharmacological properties. Br J Pharmacol 158: 1153-1164, 2009.

17. Wang XK, He Jh, Xu Jh, Ye S, Wang F, Zhang H, Huang Zc, To KK and Fu Lw: Afatinib enhances the efficacy of conventional chemotherapeutic agents by eradicating cancer stem-like cells. Cancer Res 74: 4431-4445, 2014.

18. Murthy R, Borges VF, Conlin A, Chaves J, Chamberlain M, Gray T, Vo A and Hamilton E: Tucatinib with capecitabine and trastuzumab in advanced HER2-positive metastatic breast cancer with and without brain metastases: A non-randomised, open-label, phase 1b study. Lancet Oncol 19: 880-888, 2018.

19. Kulukian A, Lee P, Taylor J, Rosler R, de Vries P, Watson D, Forero-Torres A and Peterson S: Preclinical activity of HER2-selective tyrosine kinase inhibitor tucatinib as a single agent or in combination with trastuzumab or docetaxel in solid tumor models. Mol Cancer Ther 19: 976-987, 2020. 
20. Lee A: Tucatinib: First approval. Drugs 80: 1033-1038, 2020.

21. Borges VF, Ferrario C, Aucoin N, Falkson C, Khan Q, Krop I, Welch S, Conlin A, Chaves J, Bedard PL, et al: Tucatinib combined with ado-trastuzumab emtansine in advanced ERBB2/HER2-positive metastatic breast cancer: A phase 1b clinical trial. Jama Oncol 4: 1214-1220, 2018.

22. Filho OM, Leone JP, Li T, Tan-Wasielewski Z, Trippa L, Barry WT, Younger J, Lawler E, Walker L, Freedman RA, et al: Phase I dose-escalation trial of tucatinib in combination with trastuzumab in patients with HER2-positive breast cancer brain metastases. Ann Oncol 31: 1231-1239, 2020.

23. Li J, Kumar P, Anreddy N, Zhang YK, Wang YJ, Chen Y, Talele TT, Gupta K, Trombetta LD and Chen ZS: Quizartinib (AC220) reverses ABCG2-mediated multidrug resistance: In vitro and in vivo studies. Oncotarget 8: 93785-93799, 2017.

24. Sugimoto Y, Tsukahara S, Imai Y, Sugimoto Y, Ueda K and Tsuruo T: Reversal of breast cancer resistance protein-mediated drug resistance by estrogen antagonists and agonists. Mol Cancer Ther 2: 105-112, 2003.

25. Wang DS, Patel A, Shukla S, Zhang YK, Wang YJ, Kathawala RJ, Robey RW, Zhang L, Yang DH, Talele TT, et al: Icotinib antagonizes ABCG2-mediated multidrug resistance, but not the pemetrexed resistance mediated by thymidylate synthase and ABCG2. Oncotarget 5: 4529-4542, 2014.

26. Shi Z, Tiwari AK, Shukla S, Robey RW, Singh S, Kim IW, Bates SE, Peng X, Abraham I, Ambudkar SV, et al: Sildenafil reverses ABCB1- and ABCG2-mediated chemotherapeutic drug resistance. Cancer Res 71: 3029-3041, 2011.

27. Wang XH, Wang XK, Liang YJ, Shi Z, Zhang JY, Chen LM and Fu LW: A cell-based screen for anticancer activity of 13 pyrazolone derivatives. Chin J Cancer 29: 980-987, 2010.

28. Shi Z, Liang YJ, Chen ZS, Wang XH, Ding Y, Chen LM and Fu LW: Overexpression of survivin and XIAP in MDR cancer cells unrelated to P-glycoprotein. Oncol Rep 17: 969-976, 2007.

29. Shi Z, Parmar S, Peng XX, Shen T, Robey RW, Bates SE, Fu LW Shao Y, Chen YM, Zang F and Chen ZS: The epidermal growth factor tyrosine kinase inhibitor AG1478 and erlotinib reverse ABCG2-mediated drug resistance. Oncol Rep 21: 483-489, 2009.

30. Ji N, Yang Y, Cai CY, Lei ZN, Wang JQ, Gupta P, Teng QX, Chen ZS, Kong D and Yang DH: VS-4718 antagonizes multidrug resistance in ABCB1- and ABCG2-overexpressing cancer cells by inhibiting the efflux function of $\mathrm{ABC}$ transporters. Front Pharmacol 9: 1236, 2018.

31. Percival ME, Lai C, Estey E and Hourigan CS: Bone marrow evaluation for diagnosis and monitoring of acute myeloid leukemia. Blood Rev 31: 185-192, 2017.

32. Vieyra DS, Rosen A and Goodell MA: Identification and characterization of side population cells in embryonic stem cell cultures. Stem Cells Dev 18: 1155-1166, 2009.

33. Ji N, Yang Y, Lei ZN, Cai CY, Wang JQ, Gupta P, Xian X, Yang DH, Kong D and Chen ZS: Ulixertinib (BVD-523) antagonizes ABCB1- and ABCG2-mediated chemotherapeutic drug resistance. Biochem Pharmacol 158: 274-285, 2018.

34. Dai Cl, Tiwari AK, Wu CP, Su XD, Wang SR, Liu Dg, Ashby CJ JR, Huang Y, Robey RW, Liang YJ, et al: Lapatinib (Tykerb, GW572016) reverses multidrug resistance in cancer cells by inhibiting the activity of ATP-binding cassette subfamily B member 1 and $G$ member 2. Cancer Res 68: 7905-7914, 2008.

35. Cai CY, Zhai H, Lei ZN, Tan CP, Chen BL, Du ZY, Wang JQ, Zhang YK, Wang YJ, Gupta P, et al: Benzoyl indoles with metabolic stability as reversal agents for ABCG2-mediated multidrug resistance. Eur J Med Chem 179: 849-862, 2019.

36. Jing W, Zhang X, Chen R, Ye X, Zhou M, Li W, Yan W, Xuyun X and Peng J: KD025, an anti-adipocyte differentiation drug, enhances the efficacy of conventional chemotherapeutic drugs in ABCG2-overexpressing leukemia cells. Oncol Lett 20: 309, 2020.

37. Litman T, Druley TE, Stein WD and Bates SE: From MDR to MXR: New understanding of multidrug resistance systems, their properties and clinical significance. Cell Mol Life Sci 58: 931-959, 2001
38. Spagnuolo P: Interactions between nutraceutical supplements and standard acute myeloid leukemia chemotherapeutics. J Pharm Pharm Sci 18: 339-343, 2015.

39. List AF: The role of multidrug resistance and its pharmacological modulation in acute myeloid leukemia. Leukemia 10 (Suppl 1): S36-S38, 1996.

40. Polgar O and Bates SE: ABC transporters in the balance: Is there a role in multidrug resistance? Biochem Soc Trans 33: 241-245, 2005.

41. Robey RW, Pluchino KM, Hall MD, Fojo AT, Bates SE and Gottesman MM: Revisiting the role of $\mathrm{ABC}$ transporters in multidrug-resistant cancer. Nat Rev Cancer 18: 452-464, 2018.

42. Robey RW, To KK, Polgar O, Dohse M, Fetsch P, Dean M and Bates SE: ABCG2: A perspective. Adv Drug Deliv Rev 61: 3-13, 2009.

43. Carrillo IO, Peñafiel CR, Peralta EM, Fuller ER, Ipiña JJ, Cruz FC, Guerrero EG, Jaloma JC, Vargas KN and Tovar AM: Clinical significance of the ABCB1 and ABCG2 gene expression levels in acute lymphoblastic leukemia. Hematology 22: 286-291, 2017.

44. Jiang ZP, Zhao XL, Takahashi N, Angelini S, Dubashi B, Sun L and Xu P: Trough concentration and ABCG2 polymorphism are better to predict imatinib response in chronic myeloid leukemia: A meta-analysis. Pharmacogenomics 18: 35-56, 2017.

45. Wang F, Wang XK, Shi CJ, Zhang H, Hu YP, Chen YF and $\mathrm{Fu} \mathrm{LW}$ : Nilotinib enhances the efficacy of conventional chemotherapeutic drugs in $\mathrm{CD} 34^{+} \mathrm{CD} 38^{-}$stem cells and $\mathrm{ABC}$ transporter overexpressing leukemia cells. Molecules 19: 3356-3375, 2014.

46. Li D, Su D, Xue L, Liu Y and Pang W: Establishment of pancreatic cancer stem cells by flow cytometry and their biological characteristics. Int J Clin Exp Pathol 8: 11218-11223, 2015.

47. Russo A, Franchina T, Ricciardi GR, Smiroldo V, Picciotto M, Zanghì M, Rolfo $\mathrm{C}$ and Adamo V: Third generation EGFR TKIs in EGFR-mutated NSCLC: Where are we now and where are we going. Crit Rev Oncol Hematol 117: 38-47, 2017.

48. Kouhpeikar H, Butler AE, Bamian F, Barreto GE, Majeed M and Sahebkar A: Curcumin as a therapeutic agent in leukemia. J Cell Physiol 234: 12404-12414, 2019.

49. Arrigoni E, Del RM, Galimberti S, Restante G, Rofi E, Crucitta S, Baratè C, Petrini M, Danesi R and Di Paolo A: Concise review: Chronic myeloid leukemia: Stem cell niche and response to pharmacologic treatment. Stem Cells Transl Med 7: 305-314, 2018.

50. Dohse M, Scharenberg C, Shukla S, Robey RW, Volkmann T, Deeken JF, Brendel C, Ambudkar SV, Neubauer A and Bates SE: Comparison of ATP-binding cassette transporter interactions with the tyrosine kinase inhibitors imatinib, nilotinib, and dasatinib. Drug Metab Dispos 38: 1371-1380, 2010.

51. Wang X, Goldstein D, Crowe PJ and Yang JL: Next-Generation EGFR/HER tyrosine kinase inhibitors for the treatment of patients with non-small-cell lung cancer harboring EGFR mutations: A review of the evidence. Onco Targets Ther 9: 5461-5473, 2016.

52. Murthy RK, Loi S, Okines A, Paplomata E, Hamilton E, Hurvitz SA, Lin NU, Borges V, Abramson V, Anders C, et al: Tucatinib, trastuzumab, and capecitabine for HER2-positive metastatic breast cancer. N Engl J Med 382: 597-609, 2020.

53. Lin NU, Borges V, Anders C, Murthy RK, Paplomata E, Hamilton E, Hurvitz S, Loi S, Okines A, Abramson V, et al: Intracranial efficacy and survival with tucatinib plus trastuzumab and capecitabine for previously treated HER2-positive breast cancer with brain metastases in the HER2CLIMB trial. J Clin Oncol 38: 2610-2619, 2020.

This work is licensed under a Creative Commons Attribution-NonCommercial-NoDerivatives 4.0 International (CC BY-NC-ND 4.0) License. 